Ольга Пинчук, Тимур Миняжев

\title{
РЫНКИ И РЕСТОРАНЫ МОСКВЫ: СЕТЕВЫЕ СООБЩЕСТВА ТРУДОВЫХ МИГРАНТОВ ИЗ АЗЕРБАЙДЖАНА
}

В статье рассматривается участие трудовых мигрантов из Азербайджана
в двух сферах занятости в Москве: рыночная инфраструктура и обще-
ственное питание. Проверяя гипотезу о присутствии азербайджанских
предпринимателей в столичных «этнических кафе», исследователи об-
наружили два сообщества трудовых мигрантов: «сообщество работников
ресторанов» и «сообщество работников рыночной инфраструктуры».
Рассматривая сообщества мигрантов из Азербайджана через призму
сетевого подхода и концепцию социального капитала, пространство
возможностей для каждого мигранта задается на основе уже имеющегося
набора связей с другими мигрантами. Сообщество характеризуется
плотностью социальных связей, оно не всегда локализовано в простран-
стве. Включенность в сетевое пространство обеспечивает мигранту
доступ к социальному капиталу сообщества, что помогает не только
начать свой «миграционный путь», но и успешно его продолжить. Чем
плотнее социальные связи, тем больше у мигранта шансов добиться
лучшего социально-экономического положения. Два сообщества трудовых
мигрантов из Азербайджана в Москве функционируют по-разному. Члены
«рыночного сообщества» имеют плотные связи в рамках одного рынка,
и слабые «межрыночные» связи, что, однако, не мешает мигрантам при
желании легко находить работу на другом рынке столицы. «Ресторанное
сообщество» не имеет конкретной локации, его члены рассредоточены
по удаленным друг от друга ресторанам, но поддерживают активную
связь «по телефону». Авторы делают вывод о том, что сообщества связаны
слабо и однонаправленно: зафиксирована лишь возможность перехода

Ольга Владимировна Пинчук-аспирант кафедры теоретической и специальной социологии Института социально-гуманитарного образования Московского педагогического государственного университета (МПГУ), Москва, Россия. Электронная почта: Pinchuk_olya@list.ru

Тимур Рифатович Миняжев-к.с.н., доцент кафедры теоретической и специальной социологии Института социально-гуманитарного образования Московского педагогического государственного университета (МПГУ), Москва, Россия. Электронная почта: Minyazhev@gmail.com 
из «рыночного сообщества» в «ресторанное». При этом, как правило, мигранты, совершившие этот условный переход, обратно на рынок уже не возвращаются.

Ключевые слова: мигранты, азербайджанцы, сетевые сообщества, рынок труда, ресторанный бизнес, полевое исследование, рыночное сообщество, диаспора, этническая группа

DOI: $10.17323 / 727-0634-2017-15-2-251-266$

За последние два десятилетия международная миграция приобрела большое значение для современной социальной и экономический жизни, что обеспечило этой теме важное место в текущей политике и академических дискуссиях (см., напр., Freeman, Mirilovic 2016). Исследователи, эксперты и политические деятели обращают внимание на разнообразие социальных проблем, связанных с миграцией, а также на вопросы использования возможностей социальной и миграционной политики для регулирования миграционного процесса. Миграция не приводит к трансформациям в социальном обеспечении и развитию соответствующих социальных институтов, в отличие, например, от стран ЕС (Кондратьева, Потемкина 2015). С другой стороны, необходимо отметить, что устойчивая трудовая миграция на протяжении многих лет могла внести серьезные изменения в структуру поля этнического разделения труда. Наша статья - приближение к теме исследования этнического рынка труда на примере изучения деятельности сообществ трудовых мигрантов из Азербайджана.

Согласно данным официальной статистики, за последние двадцать лет наибольшее число граждан Азербайджанской Республики прибыло на территорию России в 1997 г. (29878 человек), наименьшее число (2584 человека) - в 2004 г. (Федеральная служба государственной статистики 2016). Ежегодно в РФ въезжают порядка 20-25 тыс. граждан Азербайджана, в настоящий момент находятся около 520 тыс. (ФМС 2016). Некоторое количество выходцев из Азербайджана имеют гражданство РФ, проживают на территории столичного региона и заняты на неквалифицированных работах. Назвать их «мигрантами» довольно сложно, хотя бы из-за наличия российского гражданства, однако характер трудовой деятельности, периодические денежные трансферы «домой» (см.: Абашин 2016: 167), доступ к социальному капиталу сообществ трудовых мигрантов включает таких «азербайджанцев» в поле миграционных исследований.

Основной вопрос, на который мы пытаемся ответить в данной статье: что представляют из себя сообщества трудовых мигрантов из Азербайджана в Москве и каким образом они функционируют. Полевой этап исследования длился в течение двух месяцев и включал в себя: (1) наблюдения в ресторанах, так или иначе маркированных как «азербайджанские», и на столичных рынках (всего около 40 часов наблюдения); (2) глубинные неструктуриро- 
ванные интервью с выходцами из Азербайджана, занятыми на рынках и в ресторанах, «азербайджанцами»-посетителями кафе и экспертами, представителями диаспоральной организации «Всероссийский азербайджанский конгресс» (15 интервью).

\section{«Азербайджанец» и «мигрант»}

«Азербайджанцы»-категория скорее географическая, нежели этническая, в широком смысле включает в себя этнически неоднородное население государства Азербайджан. В разговорах с информантами об их соотечественниках в Москве мы ни раз обращали внимание на особое выделение таких этнических подкатегорий как «горские евреи», проживающие в основном в Губинском районе Азербайджана, «талыши», жители Ленкоранского района, и «бакинские русские». В число наших информантов не вошли «бакинские русские» и «горские евреи», о них мы знаем лишь со слов других выходцев из Азербайджана. Остальные участники исследования, как правило, называли себя «азербайджанцами».

Сложность заключается еще и в том, что нет общего понимания термина «мигрант» (Абашин 2012: 4; Гулина 2016:332). Как было показано выше, с точки зрения здравого смысла мы не можем безоговорочно называть участников исследования «мигрантами», как минимум потому, что некоторые из них имеют российское гражданство. При этом на уровне обывательского восприятия

...под «мигрантом» имеется в виду вовсе не русский, приехавший из Баку, Ташкента или Владивостока в Москву или Питер, и скорее всего даже не украинец и не белорус, а именно этнически «другой», который легко узнается по внешнему виду и поведению (Абашин 2012: 7).

Таким образом, используя словосочетание «трудовые мигранты из Азербайджана» и этноним «азербайджанцы» в рамках конкретного текста, мы учитываем вышеизложенные ограничения, не претендуя на окончательную трактовку понятий миграционного статуса или этничности.

В данной статье мы предлагаем посмотреть на азербайджанскую миграцию через призму концепции социального капитала (Бурдье 2002; Коулман 2001) и теории сетевого сообщества (Portes, Rumbaut 2006; Грановеттер 2009). Понятия «социальные сети» и «сетевые ресурсы» подробно разбираются в статье Дмитрия Борисова и Катерины Фофановой. Они отмечают, что в современном мире «все пронизано "сетями" социальных отношений» (2013: 191). В этом смысле «сеть» представляет собой устойчивые связи и контакты между индивидами. Если рассматривать социальное пространство в качестве сети социальных отношений, то сообеествами будут называться «фрагменты сети с высокой плотностью связей "внутри" и относительно малым количеством связей "наружу"» (Варшавер, Рочева 2014: 106). В рамках 
исследования для аналитических целей мы берем за основу понятие о «пространстве» социальных сетей, где «сообщество», с одной стороны, является его частью, с другой - «площадкой возможностей».

Сетевой характер миграции иллюстрируется тем, что сама идея о ней возникает лишь на основе знания об опыте состоявшихся мигрантов. Опыт передается потенциальным мигрантам посредством существующих социальных сетей. Этот обмен опытом возможен лишь в условиях доверия (Tilly 2007). В этой связи мы будем говорить о социальном капитале сообщества, доступ к которому обеспечивается только индивидам, включенным в сеть. Социальный капитал «способствует достижению определенных целей, добиться которых при его отсутствии невозможно» (Коулман 2001: 124), это «совокупность реальных и потенциальных ресурсов, связанных с обладанием устойчивой сетью... отношений взаимного знакомства и признания» (Бурдье 2002: 66).

Новички (newcomers) в таких сетях занимают позиции на рынке труда в зависимости от характеристик того сообщества, в которое они включаются (Portes, Rumbaut 2006:94), а также в зависимости от обладания капиталом. Мигранты, как правило, едут туда, где сообщества уже функционируют. В начале миграционной истории основная помощь идет со стороны имеющихся связей, которые и способствуют приобретению новых (Ibid:2006). Сети выступают, во-первых, источником информации о рабочих местах, о способах устройства жизнедеятельности (где и как оформить необходимые документы, найти жилье, куда идти за продуктами); во-вторых, сообщество является «центром» профессионального обучения и поддержки - способствует получению трудовых навыков, квалификации и опыта.

Отечественные ученые по-разному подходят к изучению вопросов этничности и миграции (Малахов 2015; Винокурова 2012; Мукомель 2011; Бредникова, Паченков 2002). Говоря о совокупности «одно-этничных» мигрантов в пространстве принимающего общества исследователи время от времени используют термин «диаспора» в различных контекстах (см., напр., Попков 2003). Мы же четко разделяем понятия «диаспора» и «сообщество». В первое вкладывается институциональный смысл: под «диаспорой» мы подразумеваем структурную организацию, деятельность которой осуществляется под контролем ее лидера. «Диаспора» («диаспоральная организация») в своем распоряжении имеет ресурсы и связи с властными и иными государственными органами (как на родине, так и в стране пребывания). «Диаспора» выступает посредником между государственными структурами и мигрантами-соотечественниками (Зотова 2010: 26), представляя интересы последних. При этом, согласно нашим наблюдениям «азербайджанская диаспора» в Москве не принимает никакого участия в жизни трудовых мигрантов, а представляет собой сугубо элитарное образование. Что касается «сообщества», то оно не имеет институциональной основы, характеризуется в первую очередь «особым типом отношений между людьми», основанным 
на «доверии, солидарности и тесных связях» (Варшавер, Рочева 2014: 105). Для дальнейшего анализа это различение имеет большое значение.

\section{Мигранты из Азербайджана на столичном рынке труда}

Согласно результатам наблюдения, рыночная инфраструктура и общественное питание - две основные сферы занятости трудовых мигрантов из Азербайджана в Москве. На их основе сложились два полноценных сообщества: «сообщество работников ресторанов азербайджанской кухни» и «сообщество работников рыночной инфраструктуры». Сообщество работников ресторанов не имеет конкретного места встречи и относительно равномерно рассредоточено по всему городу. Что же касается «рыночного сообщества», то здесь наблюдается наибольшая концентрация связей в рамках одной локации (инфраструктуры данного рынка), куда входят и хозяева точек, и продавцы, и работники рыночных кафе.

На пилотажном этапе исследования коллегами была зафиксирована высокая плотность связей, воспроизводящихся «азербайджанскими предпринимателями» в рамках кафе и ресторанов разного уровня, равномерно распределенных по Москве. То есть кафе и рестораны рассматривались в качестве «пространственной основы функционирования» сообщества (Варшавер, Рочева 2014), получившего условное название «азербайджанский бизнес». Таким образом, для проработки гипотезы о сообществе «азербайджанских предпринимателей» было решено искать информантов в пространствах кафе и ресторанов столицы (так или иначе маркированных как «азербайджанские»). Изначально кафе и рестораны в рамках проекта признавались «этническими» по трем критериям: (1) наличие блюд национальной кухни в меню заведения, (2) преобладание представителей «видимых меньшинств» среди работников ресторана, (3) присутствие представителей «видимых меньшинств» среди посетителей (Варшавер и др. 2014).

В процессе полевого исследования оказалось, что рестораны азербайджанской кухни различаются по формату, составу целевой аудитории, способу ведения бизнеса. И после нескольких выходов в поле стало очевидно, что третий критерий «этничности» кафе (присутствие условных «азербайджанцев» среди посетителей) в ряде случаев не имеет значения: некоторые предприятия ориентированы на широкую аудиторию. Именно эта категория ресторанов выступает основой функционирования сообества мигрантовработников ресторанов, но не «азербайджанских предпринимателей» (как предполагалось изначально). В то же время наиболее «этническими» (по трем критериям) можно считать небольшие «рыночные кафе», функционирующие в пространствах столичных рынков.

Именно обнаружение последнего факта привело нас на рынки Москвы, где в ходе интервью и наблюдений удалось зафиксировать высокую 
плотность связей приехавших из Азербайджана работников рынков. Таким образом, в рамках данного исследования, необходимо выделить два разных типа предприятий общественного питания, ставших локациями сбора данных. Первый тип - это рестораны азербайджанской кухни, ориентированные прежде всего на широкую публику. Они адаптированы под клиента и предлагают свои услуги практически в каждом районе города. Работают в них, в основном, мигранты из Азербайджана. Однако встречаются также узбеки, армяне, таджики, молдаване, русские, украинцы и др. Такие рестораны «образовывают» на своей основе «сообщество работников ресторанов азербайджанской кухни».

Второй тип - «рыночные кафе». В процессе исследования выяснилось, что интенсивные социальные связи проявляются на рынках, где занята часть мигрантов из Азербайджана. Рыночная инфраструктура помимо торговых площадей, включает в себя небольшие кафе. В противоположность ресторанам для широкой публики, «рыночные кафе»-только для «своих»: среди гостей здесь преобладают мигранты из Азербайджана, трудоустроенные на том же рынке. Эти заведения успешно вписаны в контекст рыночной инфраструктуры, и часто являются ее производными. Здесь мы будем говорить о «сообществе работников столичных рынков». Работники «рыночных кафе» не имеют интенсивных связей с работниками ресторанов первого типа.

\section{Сообщество работников ресторанного бизнеса}

В это сообщество включены мигранты из Азербайджана, занятые в столичных ресторанах азербайджанской кухни. Обширные социальные связи, как правило, сосредоточены вокруг вопросов трудоустройства. Ежедневный обмен данными позволяет создавать и поддерживать «информационную базу» сообщества. Такая база нигде конкретно не зафиксирована, она «на слуху» и передается вербально от одного члена сообщества к другому. В данном случае сообщество - это обширная сеть знакомств, которые не поддерживаются постоянными личными встречами:

\footnotetext{
У меня есть знакомые в других ресторанах. Общаемся по телефону в основном... Иногда я звоню, иногда мне звонят и говорят: «Приехал повар, работа нужна» (Управляющий рестораном, из полевого дневника).
}

По словам информантов, в их записных книжках от 40 до 200 активных контактов. Ими пользуются, если: (1) работа необходима самому информанту, его коллеге/знакомому/родственнику; (2) в ресторане открыта вакансия, которую надо как можно быстрее закрыть. Поэтому владельцы ресторанов «азербайджанской кухни», согласно нашим наблюдениям, в сообщество включены довольно слабо - в этом нет необходимости: самостоятельно подбором персонала они, как правило, не занимаются. 


\section{Функционирование сетей “ресторанного сообщества»}

По степени включенности и уровню влияния в сообществе можно выделить три основные группы: (1) владельцы ресторанов азербайджанской кухни; (2) «социально активные работники»; (3) «социально пассивные работники». Владельцы ресторанов азербайджанской кухни слабо включены в сообщество. Информанты замечали, что крупные предприниматели, владеющие ресторанами азербайджанской кухни, имеют разнообразное происхождение, и их определенно нельзя назвать «трудовыми мигрантами». Они все же включены в сообщество (пусть и слабо), но лишь в качестве тех, кто дает работу трудовым мигрантам. Характерно, что такие бизнесмены, как правило, редко появляются в своих заведениях,- управление чаще передано в руки «доверенному лицу» (в больших ресторанах это управляющие, в маленьких - администраторы или «смотрители» $\left.{ }^{1}\right)$.

К «социально активным работникам» относятся мигранты, работающие в «азербайджанских ресторанах» и активно включенные в коммуникационное поле сообщества. Основной характеристикой членов данной группы является высокая интенсивность связей с другими членами сообщества, а не профессиональная позиция или социальный статус. Чаще всего «социально активные работники» - это: (а) «доверенные лица» (работают по найму, связанны с высшим руководством и занимают управленческие должности); (б) работники, лишенные прямой связи с руководством, но имеющие некоторые управленческие функции (администраторы, имеют подчиненных, напрямую подчиняются управляющему, но не контактируют с хозяином заведения); (в) работники, напрямую взаимодействующие с руководством, но не имеющие управленческих функций (например, повара). Повара включены в сеть очень активно. По словам информантов, «кавказские блюда хорошо готовят только "свои" - знают специфику» (из полевого дневника). Наши собеседники, занятые в ресторанах азербайджанской кухни, ни раз указывали на то, что повара здесь часто меняют место работы:

Частая смена работы - это правильно, заводишь новые знакомства, набираешься опыта с разными людьми и в разных условиях (Повар, из полевого дневника).

При этом такая мобильность не характерна, например, для официантов, администраторов или управляющих. Периодическая смена места трудоустройства - это один из способов расширить сеть личных связей внутри сообщества и обогатить свой профессиональный опыт. В среднем, повара меняют работу один-два раза в год. Чтобы это было реальным, поварам важно всегда иметь доступ к «информационной базе» сообщества.

\footnotetext{
1 Лицо, как правило, официально не трудоустроенное в заведении, но осуществляющее при этом весь комплекс управленческих функций.
} 
В некоторых случаях официанты могут выступать «социально активными работниками»: при условии, что они обладают интенсивными связями с другими членами сообщества. Это имеет смысл, когда официант работает несколько лет на одном месте (круг знакомств расширяется за счет текучки кадров) или в случае, если за небольшое количество времени поменял несколько мест работы (и сохранил связи с бывшими коллегами).

«Социально пассивные работники»- это чаще всего новички без квалификации, приехавшие недавно. До иммиграции они не имели значимых социальных связей и по какой-то причине не обзавелись ими по приезде. Таким образом, периферия ресторанного сообщества включает в себя владельцев ресторанов и «социально пассивных работников», две невзаимодействующие группы в рамках одного сообщества. Обе эти группы имеют одинаково слабые связи с другими членами сообщества, но разную степень влияния. Владельцы бизнеса выступают в качестве работодателей, и наличие контактов с ними облегчает поиск работы. Они включены в сообщество преимущественно посредством своих «доверенных лиц», которые в свою очередь имеют развернутую сеть социальных связей. Единственное, что могут предложить сообществу «социально пассивные работники»,--это собственный физический труд.

«Социально активные работники» являются ядром сообщества. Они осуществляют общую коммуникацию, объединяя социально-удаленные части сообщества в одну обширную социальную сеть. Например, администратор У. всегда на связи с коллегами по телефону: нередко к нему в ресторан приходят люди в поисках работы, и, если он сам ничего предложить не может, то звонит знакомым и узнает о наличии открытых вакансий. Благодаря У. происходит включение новых членов в сообщество. Сам же администратор таким образом поддерживает и расширяет свои социальные связи с другими участниками.

\section{Качества сетей “ресторанного сообщества»}

В сети социальных связей ресторанного сообщества включены выходцы из разных районов Азербайджана. Ориентация на земляков (выходцев из конкретного района Азербайджана) в некоторой степени характерна для новоприбывших, но только потому, что они еще не имеют знакомых в Москве (кроме родственников или соседей с места проживания на родине). Нередки случаи, когда уроженцы одного азербайджанского района помогают незнакомым азербайджанцам того же района устроиться на работу. Однако в целом, «земляческий принцип» не является ведущим в процессе «наращивания» личной сети связей.

А.-администратор ресторана, который по приезде в Москву несколько месяцев не мог найти работу. Он пробовал устроиться в рестораны и кафе восточной кухни, но «опыта не было, не брали никуда». Однажды знакомые рассказали о ресторане «Х», владельцами которого являются земляки А. 
Его взяли туда помощником официанта и всему научили в процессе работы. За два года А. поднялся по карьерной лестнице до уровня администратора.

Таким образом, «ресторанное сообеетво» включает мигрантов из Азербайджана, работающих в ресторанах азербайджанской кухни в разных районах столицы. Связь между ними поддерживается преимущественно «по телефону». Основные вопросы, решаемые членами сообщества,-это поиск работы и сотрудников.

\section{Сообщество работников столичных рынков}

Рынок включает торговые точки и «рыночные кафе». Наше внимание было обращено на кафе, где собираются мигранты из Азербайджана. На столичных рынках нередко встречаются именно талыши: они работают продавцами и управляющими торговых точек, иногда имеют собственный мелкий бизнес, они же составляют большую часть посетителей и работников «рыночных кафе», известных исследователям. Об особой «талышской» идентичности информанты говорили довольно часто:

Мы как-то отдельно от других азербайджанцев... Наши на рынках везде, все мы знакомы друг с другом... У нас и язык другой.. Мы знаем, что есть, например, район Губа, может кого и знаем оттуда, но не очень-то общаемся... Со своими больше, у нас и язык свой (из полевого дневника).

«Свой (другой) язык», о котором дважды говорит Ф., администратор оптовой овощной точки на рынке, является чуть ли не основной отличительной чертой «талышей», которые также свободно владеют азербайджанским языком. Фраза «другие азербайджанцы» говорит о включении информантом талышей в совокупность «азербайджанцы», но акцентирует внимание на ее неоднородности. «Талыш» - это самоидентификация наших собеседников на рынках, также их называют и «другие азербайджанцы»:

На российских рынках - все талыши!.. Иногда они ведут себя неподобающе! А на них ведь и русские люди смотрят... И я думаю, какое плохое впечатление про нас складывается... про весь наш азербайджанский народ $<\ldots>$ Не то, чтобы они плохие... я считаю их своими соотечественниками! (из полевого дневника)

Автор последней цитаты - Г., повар из Губинского района (с самого начала уточнивший, что не является «горским евреем»). Он работает в Москве более десяти лет, отлично говорит на русском языке, интересуется историей своей семьи и своего региона. Он является «внешним наблюдателем» по отношению к участникам рыночного сообщества - посещает рынок в районе проживания, чтобы закупиться продуктами. Характеристика талышей (соотечественников, работающих на рынке), о которой он 
говорит, как об их «неподобающем поведении», повторялась в большинстве интервью с «азербайджанцами», работающими в ресторанах.

\section{Функционирование рыночного сообщества}

Социальные сети рыночного сообщества охватывают все крупные рынки столицы. Но интенсивность связей между членами рыночного сообщества неоднородна. Она сильнее в рамках одного рынка и заметно слабее между разными рынками, территориально удаленными друг от друга. Наиболее интенсивные связи локализованы в пределах конкретного пространства - на каждом отдельном рынке. В частом взаимодействии между разными рынками столицы нет большой необходимости, но такие связи существуют.

«Межрыночные» связи используются в первую очередь с целью трудоустройства. Например, один из работников оптовой базы на юге Москвы изначально приехал к своему брату на рынок Х., где несколько месяцев работал грузчиком. Благодаря приобретенным в процессе работы знакомствам, вскоре он перебрался на юг столицы уже в качестве продавца.

Но заметно чаще карьерные траектории членов сообщества встроены в пространство одного рынка. Поэтому поиск работы «по телефону» здесь не распространен. Нередко свою карьеру на рынке мигранты начинают с работы грузчиком. Это «тупиковая трудовая позиция», которая не сулит профессионального развития, поэтому ее скорее занимают «временные мигранты», приехавшие на краткосрочные заработки. Если после нескольких месяцев мигрант не принимает решения вернуться домой, следующим шагом будет переход на более «комфортную» работу, нередко в рамках того же рыночного пространства:

Д. работал сначала грузчиком - таскал мешки, коробки. Тяжело, говорит, было, а когда холода пришли - особенно. Зимой решил поменять профиль: попросился официантом в кафе на том же рынке (из полевого дневника).

На рынке определенная часть мигрантов работает вахтовым методом: четыре-пять месяцев в Москве, остальное время проводят дома. При этом место их работы, как правило, не меняется несколько лет. Они работают на одной торговой точке, которую оставляют с наступлением холодов и возвращаются с потеплением. Важно, что их социальные связи не теряются за период отсутствия на рабочем месте: эти связи либо поддерживаются на родине, либо сохраняются в «спящем режиме» и воспроизводятся по возвращении. Чаще такого режима миграции придерживаются работники оптовых точек, в отличие от работников рыночных кафе и розничных торговых точек, которые работают круглый год.

В рамках одного рынка могут образовываться отдельные группы членов «рыночного сообщества», с более интенсивными внутренними связями и менее интенсивными внешними. Например, на территории одного рынка, 
может быть несколько «рыночных кафе», при этом за конкретным заведением в той или иной степени будут «закреплены» постоянные клиенты. При наличии нескольких вариантов, кафе выбирается по принципу удобства: близость к месту работы, дружеские или родственные связи.

Работники рынка связаны в сеть не только интересом трудоустройства, как в случае «ресторанного сообщества». Нередко они имеют близкие, дружеские отношения. Такие социальные связи воспроизводятся практически ежедневно, так как работа на рынке занимает большую часть времени: с четырех утра и до позднего вечера с редкими выходными. «Рыночные кафе» здесь являются местом встречи соотечественников. За счет тесных личных связей возникает возможность решать не только вопросы трудоустройства, но также более общего характера. Например, можно узнать, где дешевле снять жилье, в какой детский сад или школу отдать ребенка. Владельцы «рыночных кафе» достаточно активно включены в социальную сеть «рыночного сообщества». Они довольно часто появляются в своих заведениях: для контроля работы и для общения с гостями.

С другой стороны, «рыночные кафе» вступают в коммерческие отношения со своими посетителями: хозяин кафе «3.», закупающий продукты на ближайшей точке, говорит, что «это удобно: можно всегда брать свежее и не надо заказывать машину». Владельцы таких «рыночных кафе»- обычно талыши. Начинают они нередко с самых тяжелых и низкооплачиваемых профессий:

Я работал на [другом] рынке около трех лет, последние пять лет я здесь. Работал грузчиком, продавцом, официантом. Теперь у меня это кафе и точка на рынке (мелкий предприниматель, из полевого дневника).

Среди работников «рыночных кафе» не все хорошо владеют русским языком, что исключает для них ряд возможностей. В первую очередь трудоустройство в азербайджанских ресторанах, на базе которых образуется «ресторанное сообщество». То есть процесс включения в «ресторанное сообщество» для определенной части рыночных работников осложнен. В таком случае «рыночные кафе» являются хорошим шансом трудоустроиться, выполняя при этом также функцию «центров адаптации» новоприбывших к условиям жизни в Москве. Здесь в процессе работы мигранты обучаются необходимым навыкам и осваивают русский язык, который помогает им лучше встраиваться в контекст принимающего общества.

«Рыночное сообщество» объединяет работников разной квалификации и социального статуса. Особенностью взаимоотношений членов сообщества являются горизонтальные социальные связи. Более интенсивные связи воспроизводятся на каждом конкретном рынке, где все работники в той или иной степени связаны между собой. «Рыночные кафе» являются местом встречи мигрантов из Азербайджана, занятых на рынке, в пространстве которых решаются не только профессиональные вопросы, но и бытовые. 


\section{Заключение}

В процессе исследования не было зафиксировано взаимодействия между двумя сообществами трудовых мигрантов из Азербайджана. Для работников рынка проще найти работу на другом столичном рынке, чем в ресторане азербайджанской кухни. Это связано с отсутствием определенной квалификации и социальных связей, плохим владением русским языком. Помимо прочего, участники рыночного сообщества не демонстрировали особого желания сменить профиль деятельности. На рынках в большинстве своем преобладают «талыши» (жители Ленкоранского района), что, возможно, является ключевой особенностью рыночного сообщества и причиной замкнутости в рамках рыночной инфраструктуры. Участники ресторанного сообщества, как правило, причисляли талышей к числу своих соотечественников, «азербайджанцев», но нередко выражали свое сожаление по поводу их «безграмотности» или «невоспитанности».

Итак, «азербайджанцы» в Москве не представляют единого гомогенного этнического сообщества. Условно, они подразделяются на два сообщества по сферам занятости - «сообщество работников ресторанного бизнеса» и «сообщество работников рыночной инфраструктуры». Эти сообщества складывались на протяжении длительного периода времени и сегодня обладают существенными материальными и человеческими ресурсами. При этом участники рыночного сообщества, в основном, являются земляками.

В результате исследования мы пришли к выводу, что чем шире сети личных знакомств, тем быстрее осуществляется доступ к ресурсам сообщества, включающим человеческий капитал и «информационную базу». Последняя воспроизводится устно и чаще используется для решения вопросов трудоустройства. Ресурсы сообщества помогают новоприбывшим устроиться на новом месте, но не обеспечивают оптимальную и эффективную адаптацию к условиям социальной и экономической жизни. Проблемным так же остается вопрос взаимодействия с местным населением. Имея достаточное количество ресурсов внутри сообщества, мигранты не стремятся налаживать связи с кемто извне, не считая случаев, когда это необходимо для развития бизнеса. Потому, для решения вопросов адаптации и интеграции трудовых мигрантов из Азербайджана в Москве необходимо разрабатывать программы и мероприятия, дающие мигрантам возможность включаться в повседневность принимающего сообщества и комфортно привыкать к жизни на новом месте.

\section{Выражение благодарности и признательности}

Статья подготовлена на основе результатов научно-исследовательского проекта «Анализ религиозных и этнических характеристик сообществ иноэтничных мигрантов в Российской Федерации», выполненного Центром изучения этничности и миграции в соответствии с Государственным заданием РАНХиГС при Президенте Российской Федерации на 2014 г. В состав исследовательской группы входили Е. Варшавер, А. Рочева, О. Пинчук. Эмпирической базой статьи 
стал материал, собранный одним из авторов (О. Пинчук) в процессе работы над исследовательским проектом.

Авторы выражают благодарность Ольге Бредниковой (научный сотрудник Центра независимых социологических исследований, Санкт-Петербург) и Елене Вьюговской (научный сотрудник Лаборатории методологии федеративных исследований РАНХиГС, Москва) за помощь при подготовке статьи.

\section{Список источников}

Абашин С. (2012) Среднеазиатская миграция: практики, локальные сообщества, транснационализм. Этнографическое обозрение, (4):3-13.

Абашин С. (2016) И здесь, и там: транснациональные аспекты миграции из Центральной Азии в Россию. С. Панарин (ред.) Восток на Востоке, в России и на Западе: трансграничные миграџии и диаспоры, СПб.: Нестор-история: 159-176.

Борисов Д. М., Фофанова К. В. (2013) Сетевой ресурс как фактор интеграции иностранных трудовых мигрантов в региональный социум. Журнал исследований сочиальной политики, (2): 189-206.

Бредникова О., Паченков О. (2002) Этничность «этнической экономики» и социальные сети мигрантов. Экономическая социология, (2): 74-81.

Бурдье П. (2002) Формы капитала. Экономическая социология, (5): 60-74.

Варшавер Е.А., Рочева А. Л., Пинчук О. В. (2014) Анализ религиозных и этнических характеристик сообществ иноэтнических мигрантов в Российской Федерачии: отчет о НИР (заключительный), М.: РАНХиГС.

Варшавер Е.А., Рочева А. Л. (2014) Сообщества в кафе как среда интеграции иноэтничных мигрантов в Москве. Мониторинг общественного мнения: экономические и социальные перемены, 3 (121): 104-114.

Винокурова Д.М. (2012) О роли сетевых связей в миграции. Журнал соџиологии и соииальной антропологии, (5): 127-135.

Грановеттер М. (2009) Сила слабых связей. Пер. З. В. Котельниковой. Экономическая социология, (4): 31-50.

Гулина О. (2016) Семантика миграционных терминов. Журнал исследований социальной политики, 14 (3): 331-346.

Зотова Н. А. (2010) Узбекские общины в России: новые «диаспоры» (на примере СанктПетербурга, Астрахани, Красноярска). Исследования по прикладной и неотложной этнологии, (222): 3-28.

Кондратьева Н.Б., Потемкина О.Ю. (ред.) (2015) Миграционные проблемы в Европе и пути их решения, М.: Институт Европы РАН.

Коулман Дж. (2001) Капитал социальный и человеческий. Общественные науки и современность, 3: 122-139.

Малахов В.С. (2015) Интеграция мигрантов как административная проблема: опыт Евросоюза. Мировая экономика и международные отномения, (1): 77-87.

Мукомель В.И. (2011) Интеграция мигрантов: вызовы, политика, социальные практики. Мир России, 20 (1):34-50.

Попков В.Д. (2003) Сообщество афганских мигрантов в Москве: Вопросы структуры и идентичности. Журнал социологии и социильной антропологии, (2): 150-164.

Федеральная служба государственной статистики (2016) Миграџия/Международная миграция. Доступно по ссылке: https://goo.gl/m6tyhD (дата обращения: 25 января 2017).

ФМС (2016) Статистические сведения в отношении иностранных граждан, находящихся на территории Российской Федераџии, в половозрастном разрезе. Доступно по ссылке: https://goo.gl/kg7sBF (дата доступа: 18 сентября 2016).

Freeman G. P., Mirilovic N. (eds.) (2016) Handbook on Migration and Social Policy, Cheltenham: Edward Elgar.

Portes A., Rumbaut R. G. (2006) Immigrant America. A Portrait. $3 d$ Ed., Berkeley: University of California Press.

Tilly C. (2007) Trust Networks in Transnational Migration. Sociological Forum, (22):3-24. 
Olga Pinchuk, Timur Minyazhev

\section{MARKETS AND RESTAURANTS IN MOSCOW: TWO NETWORK COMMUNITIES OF MIGRANT WORKERS FROM AZERBAIJAN}

The article deals with two sectors of employment for Azerbaijani labor migrants in Moscow, the urban markets sector and public dining. While attempting to verify the existence of an Azerbaijani business community in 'Azeri cafes', the researchers discovered two other communities for Azerbaijani labor migrants: those employed in Azerbaijani restaurants ('the restaurants community') and those employed in urban markets' ('the urban markets community'). In accordance with this empirical data, in examining Azerbaijani labor migrants communities, the authors implemented the 'social network' approach and employed the concept of social capital. This approach is built on the idea that working opportunities for individual migrants depends on the strength of ties accumulated with other migrants. Thus, a community is based on the density of such social ties, which are strong within the community but hold relatively weak connections to the rest of society. Meanwhile it does not necessarily have any specific location. Membership to a network provides labor migrants with access to community social capital, helping them in their labor activity. This dense network of connections offers the labor migrant the opportunity to achieve the better social and economic conditions. The two communities of Azerbaijani labor migrants exist in different ways. The ties between members of 'urban markets community' are stronger within one market, and weaker with other ones. The 'Restaurants community' does not have a specific location. Its members are employed in restaurants in different parts of the city however they always keep in touch (on the phone). The authors came to conclusion that there are weak and one-way ties between the two communities of Azerbaijani labor migrants in Moscow. However, the only real contact the two communities have is in those cases when workers move from the 'urban markets community' to the 'restaurants community'. As a rule, this transition is one-way; migrants moving from markets to restaurants do not return back.

Keywords: migrants, Azerbaijanis, labor market, public dining, field research, urban markets community, diaspora, ethnic group

DOI: 10.17323/727-0634-2017-15-2-251-266

Olga Pinchuk - PhD student, Department of theoretical sociology, Institute for Social and Humanities Education, Moscow State Pedagogical University, Moscow, Russian Federation. E-mail: Pinchuk_olya@list.ru

Timur Minyazhev - kandidat nauk (PhD) in Sociology, Associate Professor, Department of theoretical sociology, Institute for Social and Humanitie's Education, Moscow State Pedagogical University, Moscow, Russian Federation. Email: Minyazhev@gmail.com 


\section{References}

Abashin S. (2012) Sredneaziatskaya migratsiya: praktiki, lokal'nye soobshchestva, transnatsionalizm [Migration from Central Asia: Practices, Local Community, Transnationalism]. Etnograficheskoe obozrenie [Ethnography Observer], (4):3-13.

Abashin S. (2016) I zdes', i tam: transnatsional'nye aspekty migratsii iz Tsentral'noy Azii v Rossiyu [Here and There: The Transnational Aspects of Migration from Central Asia to Russia]. S. Panarin (ed.) Vostok na Vostoke, v Rossii i na Zapade: transgranichnye migratsii $i$ diaspory [East in the East, in Russia and in the West: Cross-border Migrations and Diasporas], St. Petersburg: Nestor-historia: 159-176.

Borisov D., Fofanova K. (2013) Setevoy resurs kak faktor integratsii inostrannykh trudovykh migrantov v regional'nyy sotsium [Networks resource as the Factor of Integration of Foreign Labor Migrants to Regional Society]. The Journal of Social Policy Studies, (2): 189-206.

Bourdieu P. (2002) Formy kapitala [Forms of Capital]. Journal of Economic Sociology, (5): $60-74$.

Brednikova O., Pachenkov O. (2002) Etnichnost' 'etnicheskoy ekonomiki' i sotsial'nye seti migrantov [Ethnicity of 'Ethnic Economy' and Social Networks of Migrants]. Journal of Economic Sociology, (2): 74-81.

Coleman J. (2001) Kapital sotsial'nyy i chelovecheskiy [Social Capital: A Multifaceted Perspective]. Obshchestvennye nauki i sovremennost' [Social Sciences and Modernity], (3): $122-139$.

Federal State Statistics Service (2016) Migratsiya / Mezhdunarodnaya migratsiya [Migration / International Migration]. Available at: https://goo.gl/m6tyhD (accessed 25 January 2017).

FMS (2016) Statisticheskie svedeniya v otnoshenii inostrannykh grazhdan, nakhodyashchikhsya na territorii Rossiyskoy Federatsii, v polovozrastnom razreze [Statistical information on foreign nationals in the territory of Russian Federation, in the context of sex and age]. Available at: https://goo.gl/kg7sBF (accessed 18 September 2016).

Freeman G. P., Mirilovic N. (eds.) (2016) Handbook on Migration and Social Policy, Cheltenham: Edward Elgar.

Granovetter M. (2009) Sila slabykh svyazey (translated by Zoya Kotelnikova) [The Strength of Weak Ties]. Journal of Economic Sociology, (4):31-50.

Gulina O. (2016) Semantika migratsionnykh terminov [Exploring the Semantics of Migration Terminology]. The Journal of Social Policy Studies, 14 (3):331-346.

Kondratieva N., Potemkina O. (eds.) (2015) Migratsionnye problemy v Evrope i puti ikh resheniya [Migration in Europe: problems and remedies], Moscow: Institute of Europe RAS.

Malakhov V. (2015) Integratsiya migrantov kak administrativnaya problema: opyt Evrosoyuza [Immigrant Integration as an Administrative Problem: the Case of the European Union]. World Economy and International Relations, (1):77-87. 
Mukomel V. (2011) Integratsiya migrantov: vyzovy, politika, sotsial'nye praktiki [Integration of Migrants: Challenges, Policies, Social Practices]. Mir Rossii [The Universe of Russia], 20 (1):34-50.

Popkov V. (2003) Soobshchestvo afganskikh migrantov v Moskve: Voprosy struktury i identichnosti [Community of Afghan Migrants in Moscow: Questions of Structure and Identity]. The Journal of Sociology and Social Anthropology, (2): 150-164.

Portes A., Rumbaut R. G. (2006) Immigrant America. A Portrait. 3rd Ed., Berkeley: University of California Press.

Tilly C. (2007) Trust Networks in Transnational Migration. Sociological Forum, (22):3-24.

Varshaver E., Rocheva A., Pinchuk O. (2014) Analiz religioznykh i etnicheskikh kharakteristik soobshchestv inoetnicheskikh migrantov $v$ Rossiyskoy Federatsii: otchet o NIR (zaklyuchitel'nyy) [An Analysis of The Characteristics of Religious and Ethnic of Communities Other Ethnic Migrants in Russian Federation: The Research Report (final)], Moscow: RANEPA.

Varshaver E., Rocheva A. (2014) Soobshchestva v kafe kak sreda integratsii inoetnichnykh migrantov v Moskve [Café Communities as an Envirionment for the Ethnic Integration of Migrants in Moscow]. The Monitoring of Public Opinion: Economic and Social Changes Journal, 3 (121): 104-114.

Vinokurova D. (2012) O roli setevykh svyazey v migratsii [On the role of network relations in migration processes (based on sociological research data)]. The Journal of Sociology and Social Anthropology, (5): 127-135.

Zotova N. (2010) Uzbekskie obshchiny v Rossii: novye 'diaspory' (na primere Sankt-Peterburga, Astrakhani, Krasnoyarska) [Uzbek Communities in Russia: St.-Petersburg, Krasnoyarsk, Astrakhan]. Issledovaniya po prikladnoy i neotlozhnoy etnologii [Studies on Applied and Emergency Ethnology], (222):3-28. 